\title{
Photobiological hydrogen production: photochemical efficiency and bioreactor design
}

\author{
Ida Akkerman ${ }^{\mathrm{a}, *}$, Marcel Janssen ${ }^{\mathrm{b}}$, Jorge Rocha $^{\mathrm{c}}$, René H. Wijffels ${ }^{\mathrm{d}}$ \\ ${ }^{a}$ The New Delta, Laan 1933-1, 6711 NX Ede, Netherlands \\ ${ }^{\mathrm{b}}$ Food and Bioprocess Engineering Group, Wageningen University, Netherlands \\ ${ }^{\mathrm{c}}$ Chemical Engineering Department, University of Coimbra, Portugal \\ ${ }^{\mathrm{d}}$ Food and Bioprocess Engineering Group, Wageningen University, Netherlands
}

\begin{abstract}
Biological production of hydrogen can be carried out by photoautotrophic or photoheterotrophic organisms. Here, the photosystems of both processes are described.

The main drawback of the photoautotrophic hydrogen production process is oxygen inhibition. The few efficiencies reported on the conversion of light energy into hydrogen energy are low, less than $1.5 \%$ on a solar spectrum basis. However, these can be increased to $3-10 \%$, by the immediate removal of produced oxygen.

The photochemical efficiency of hydrogen production can be calculated theoretically, and is estimated to be $10 \%$ (on solar spectrum basis) for the photoheterotrophic process. With use of the theoretical photochemical efficiency, and the climatic data on sunlight irradiance at a certain location at a certain moment of the year, the theoretical maximum hydrogen production can be estimated.

Data on $\mathrm{H}_{2}$ yields and photochemical efficiency from experiments reported in the literature are summarized. Photochemical efficiencies, essentially based on artificial light, can reach $10 \%$ or even more, but only at low light intensities, with associated low- $\mathrm{H}_{2}$ production rates.

Some reflections on possible photobioreactors lead to two types of (modified) photobioreactors that might be successful for a large-scale biological hydrogen production.

(C) 2002 International Association for Hydrogen Energy. Published by Elsevier Science Ltd. All rights reserved.
\end{abstract}

Keywords: Hydrogen production; Biohydrogen; Photosynthetic bacteria; Photobioreactor; Light-energy conversion; Photochemical efficiency

\section{Introduction}

\subsection{Hydrogen: a promising energy source}

Economic growth in the last few decades was strongly dependant on fossil fuels as sources of energy. These resources are not unlimited in the long run, and environmental concerns have led to the search for clean energy sources. A few decades ago, a fuel was considered clean

\footnotetext{
* Corresponding author. Tel.: +31-318-623022; fax: +31-318-623044.

E-mail addresses: denieuwedelta@chello.nl (I. Akkerman), marcel.janssen@algemeen.pk.wau.nl (M. Janssen), rene.wijffels@ algemeen.pk.wau.nl (R.H. Wijffels).
}

when it could be burned efficiently into water and carbon dioxide $\left(\mathrm{CO}_{2}\right)$ and as little by-products as possible. This view has changed, since the problems of global warming have been recognized, and goals to reduce $\mathrm{CO}_{2}$ outputs have been defined. Hydrogen $\left(\mathrm{H}_{2}\right)$ only produces water when burned with oxygen, and is therefore an interesting fuel.

The main application of hydrogen is expected to be, in the near future, in fuel-cell powered vehicles. These vehicles have already been developed, but are still subject to optimization by car-manufacturing companies.

For large-scale use, the production of significant quantities of hydrogen economically is essential.

From a strictly economic point of view, it is difficult to expect in the next few decades that hydrogen produced biologically can compete with chemically-synthesized 
hydrogen. However, hydrogen production from residual organic substrates with phototrophic microorganisms, in connection with waste-water treatment, is a promising process. Despite the production price, the biological hydrogen production would combine the advantage of ecological production with clean combustion. Other goals, such as waste (water) treatment and carbon dioxide reduction, are served.

Before hydrogen can be used at large scale many problems related with storage, transportation and security must be solved.

\subsection{Photobiological production of $\mathrm{H}_{2}$}

Microalgae and cyanobacteria are photoautotrophic organisms because they can use light as the energy source and the carbon dioxide as carbon source. Some bacteria are termed photoheterotrophic microorganisms because in spite of their ability of using light as the energy source, they need organic carbon as the carbon source.

\subsection{Photoautotrophic $\mathrm{H}_{2}$ production}

Microalgae and cyanobacteria are able to use sunlight to metabolize carbon dioxide $\left(\mathrm{CO}_{2}\right)$ inside energy-rich organic compounds $\left[\mathrm{C}_{n}\left(\mathrm{H}_{2} \mathrm{O}\right)_{n}\right]$, with water $\left(\mathrm{H}_{2} \mathrm{O}\right)$ as an additional substrate.

Normal photoautotrophic microalgal growth:

Route A : $\quad \mathrm{CO}_{2}+\mathrm{H}_{2} \mathrm{O}+$ "light energy"

$$
\Rightarrow\left[\mathrm{C}_{n}\left(\mathrm{H}_{2} \mathrm{O}\right)_{n}\right]+\mathrm{O}_{2} \text {. }
$$

Under anaerobic conditions, microalgae can produce $\mathrm{H}_{2}$, by water photolysis, using light as the energy source. The catalyst is a hydrogenase, an enzyme that is extremely sensitive to oxygen, a by-product of photosynthesis.

$$
\begin{array}{ll}
\text { Route B : } & 4 \mathrm{H}_{2} \mathrm{O}+\text { "light energy" } \\
& \Rightarrow 2 \mathrm{O}_{2}+4 \mathrm{H}_{2}\left(\Delta G^{0}=+1498 \mathrm{~kJ}\right) .
\end{array}
$$

\subsection{Photoheterotrophic production of $\mathrm{H}_{2}$}

The ability of $\mathrm{N}_{2}$ fixation by photoheterotrophic bacteria or (heterocystous) cyanobacteria is catalysed by the nitrogenase enzyme. The nitrogenase enzyme also catalyses the evolution of $\mathrm{H}_{2}$, particularly in the absence of $\mathrm{N}_{2}$. The overall energy consuming reaction is

$\mathrm{N}_{2}+8 \mathrm{H}^{+}+8 e^{-}+16 \mathrm{ATP} \Rightarrow 2 \mathrm{NH}_{3}+\mathrm{H}_{2}+16 \mathrm{ADP}+16 \mathrm{P}_{i}$.

The conversion of the organic substrate (acetate at the example below) into hydrogen demands energy, and this is obtained from light.

$$
\begin{aligned}
& \mathrm{C}_{2} \mathrm{H}_{4} \mathrm{O}_{2 \text { liq }}+2 \mathrm{H}_{2} \mathrm{O}_{\text {liq }}+\text { "light energy" } \\
& \quad \Rightarrow 2 \mathrm{CO}_{2 \text { gas }}+4 \mathrm{H}_{2 \text { gas }}\left(\Delta G^{0}=75.2 \mathrm{~kJ}\right) .
\end{aligned}
$$

The nitrogenase enzyme is also highly sensitive to oxygen, and inhibited by ammonium ions. This explains why bioreactors must usually operate under anaerobic conditions free of $\mathrm{N}_{2}$, with illumination and limiting concentrations of nitrogen sources.

\section{Photosynthesis}

\subsection{The photosystem}

Photoautotrophic organisms such as microalgae and cyanobacteria, and photoheterotrophic bacteria, have the capacity to absorb light energy (photons) and to store it as chemical energy via the formation of chemical bonds. The basic unit of the photosynthetic apparatus is the photosystem. In this system, light energy, i.e. photons, is absorbed by carotenoid and chlorophyll pigments of the photosystem antenna complex.

A photosystem consists of an "antenna complex" of tens to hundreds of pigment molecules (cartenoids and chlorophyll $a$ and $b$ in the case of green algae) that absorb light and a "reaction centre" consisting of a strongly specialized molecule (P680) that transforms light energy into chemical energy.

A light particle (a photon) hits one of the antennae pigments. The pigment gets into an excitated condition and can transfer the excitation energy to the following antennae molecule with a lower excitation energy: the photons fall into a so-called energy hole. The excitation energy is finally used to lift the reaction centre into an excitated condition.

In the reaction centre, the excitation energy is used to transmit one electron from one chemical compound (donor) towards the other compound (acceptor). In the reaction centre actually separation of charge occurs: the excitation energy is stored into an energy-rich chemical bond.

During the transport of the energy from a photon towards the reaction centre, some energy-loss always occurs (heat loss by excitation transfer). This is the price to be paid for storage of light energy. There is sufficient energy left to induce a charge separation that produces fuel for the cell (energy available for storage). Like other examples in nature, the chemical energy storage by the cells is to satisfy their own biological activity requirements; however, this ability of the cells can be exploited for energy production.

\subsection{The photosystem of green algae; direct biophotolysis}

In oxygenic photosynthesis, two photosystems, photosystem I (PS I) and photosystem II (PS II), operate in series. The reaction centre of PSII shows the strongest absorption at $680 \mathrm{~nm}$ and is called P680. Practically this means that the excitation energy of every photon with a wavelength smaller than $680 \mathrm{~nm}$ (i.e. greater energy), absorbed by the antenna pigments, can be transferred to the reaction centre.

The PSI reaction centre, P700, absorbs most strongly at $700 \mathrm{~nm}$. PSII generates a strong oxidant capable of liberating electrons from water. The reductant delivers the 


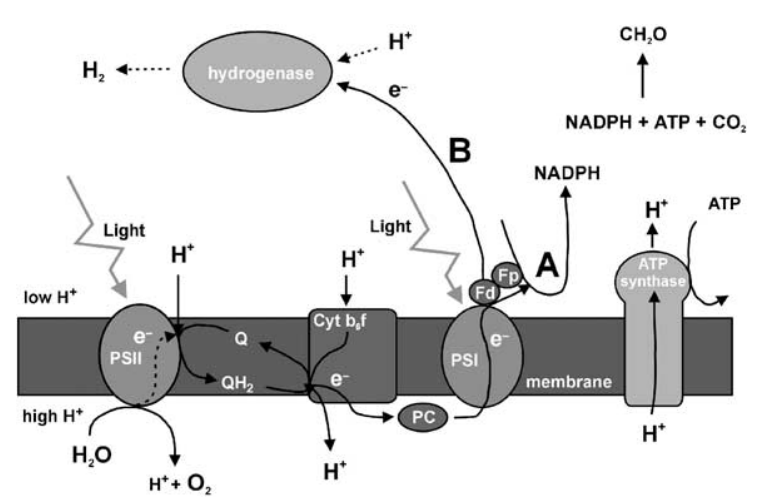

Fig. 1. The site of the 'light reactions': the thylakoid membrane, linear electron transport and production of adenosine triphosphate (ATP) via a proton driving force.

reducing equivalents via a series of electron carriers and the cytochrome $\mathrm{b}_{6} \mathrm{f}$ complex to the oxidized reaction centre of PSI. The light energy absorbed by PSI is not only used to oxidize the reaction centre, but also to produce a strong reductant capable of reducing oxidized nicotinamide adenine dinucleotide phosphate $\left(\mathrm{NADP}^{+}\right)$to NADPH.

In Fig. 1, the structure of the photosynthetic machinery is shown in more detail. Both photosystems are inserted in the lipid bilayer of the so-called thylakoid membranes. The thylakoid membranes enclose an inner space called the lumen. The strong oxidant formed after excitation of the PSII reaction centre induces the splitting of water into oxygen, electrons and protons. The protons are left in the lumen. In a continuous process, electrons are used to reduce the reaction centre, and, after renewed excitations, they are transported to plastoquinone (PQ). Protons are picked up from the surrounding medium (stroma) producing fully reduced plastoquinone $\left(\mathrm{PQH}_{2}\right)$. This membrane-soluble protein diffuses to the cytochrome $\mathrm{b}_{6} \mathrm{f}$ complex. Via the cytochrome complex, electrons are transferred to the water-soluble electron carrier plastocyanin (PC). A special mechanism inside this complex allows for additional pumping of protons across the lipid bilayer (Fig. 1). Via the lumen, plastocyanin diffuses to PSI, which acts as an oxidant after light-induced excitation. One by one, the electrons released by plastocyanin reduce the reaction centre, and, after renewed light-induced excitations, they are transported to the electron carrier ferredoxin (Fd). Finally, $\mathrm{NADP}^{+}$is reduced to NADPH via the action of ferredoxin-NADP reductase (Fp). The proton gradient across the thylakoid membrane drives adenosine triphosphate (ATP) production via the action of ATP synthase.

In eukaryotic microalgae, the thylakoid membranes are found in the chloroplast. In prokaryotic cyanobacteria, the site of photosynthesis is the plasma membrane or membranes derived from it. The energy and reducing power derived as ATP and NADPH is used to fix carbon dioxide via the action of ribulose-biphosphate carboxylase (Rubisco) in the Calvin cycle. The carbon reduction reactions take place in

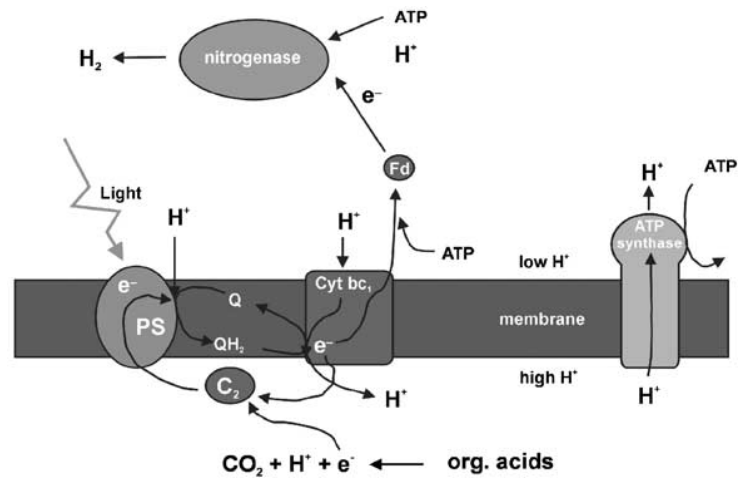

Fig. 2. Photofermentation purple bacteria.

the aqueous region of the chloroplast, the stroma, or in the cytoplasma (cyanobacteria). The product of the Calvin cycle is phosphoglyceraldehyde (triose P) and this is the building block for synthesis of fats, fatty acids, amino acids and carboxylic acids. In addition, triose $\mathrm{P}$ is the starting point for synthesis of hexose $\mathrm{P}$, followed by carbohydrate synthesis. Carbohydrates (e.g. starch) are stored and used later as energy source (respiration) and building blocks.

Route A: During normal oxygenic photosynthesis (green algae, but also cyanobacteria or blue-green algae and higher plants), the electrons of the ferrodoxine are transposed to the chemical compound NADP+. NADPH and ATP are now used to fix carbon dioxide $\left(\mathrm{CO}_{2}\right)$ as carbohydrates $\left[\mathrm{C}_{n}\left(\mathrm{H}_{2} \mathrm{O}\right)_{n}\right]$.

Route B: Under special conditions (anaerobic, very low $\mathrm{P}_{\mathrm{H} 2}$, light), the electrons that are placed on the ferrodoxin can be used to reduce protons to hydrogen $\left(\mathrm{H}_{2}\right)$. This reaction is catalyzed by the hydrogenase enzyme and does not require any extra energy in the form of ATP. This mechanism can be considered as the photobiological electrolysis of water. The hydrogenase enzyme, however, is extremely sensitive to oxygen.

\subsection{The photosystem of purple bacteria, photofermentation}

The photosynthetic device of purple bacteria is simpler, it consists of only one photosystem (PS), Fig. 2. This photosystem is also fixed in the intracellular membrane. The photosystem itself is not powerful enough to split water. Under anaerobic circumstances, however, these bacteria are able to use simple organic acids, like acetic acid, or even hydrogen disulfide as electron donor.

The electrons that are liberated from the organic carbon (for example acetate) or $\mathrm{H}_{2} \mathrm{~S}$ are pumped around through a large number of electron carriers (amongst which are Q and $\mathrm{C}_{2}$ ). During the electron transport, protons are pumped through the membrane (e.g. in the cytochrome $b_{1}$ protein complex). A proton gradient is developed (high and low $\mathrm{H}^{+}$), and this is used by the ATP synthase enzyme to 
generate ATP. The extra energy in the form of ATP can be used to transport the electrons further to the electron acceptor ferredoxin $(\mathrm{Fd})$. Under nitrogen-limited circumstances, these electrons can be used, using extra "ATP energy", by the nitrogenase enzyme to reduce molecular nitrogen into ammonium.

When molecular nitrogen is not present, this enzyme can, again with the help of extra energy in the form of ATP, reduce protons into hydrogen gas $\left(\mathrm{H}_{2}\right)$, with the electrons derived from the ferredoxin $(\mathrm{Fd})$. It has been shown that, in this way, the major component of organic acids can be transformed into hydrogen gas $\left(\mathrm{H}_{2}\right)$ and carbon dioxide $\left(\mathrm{CO}_{2}\right)$.

The nitrogenase enzyme is also sensitive to oxygen $\left(\mathrm{O}_{2}\right)$. In this case, it is not a problem because no oxygen is produced during the process (anoxygenic photosynthesis).

\subsection{Comparison of the photoautotrophic and the photoheterotrophic process}

The photoautotrophic process is very attractive because it makes energy $\left(\mathrm{H}_{2}\right)$ out of cheap and generally available sources, namely water and sunlight, and with no $\mathrm{CO}_{2}$ produced.

The most important problem connected to the photoautotrophic production is the fact that the enzymes that produce hydrogen (hydrogenases) are strongly inhibited by oxygen, while during the hydrogen production process oxygen is simultaneously produced.

Several studies concentrate on ways to overcome this problem [1]. In the future, genetic engineering might produce mutants with increased $\mathrm{O}_{2}$ tolerances.

The $\mathrm{O}_{2}$ tensions could be reduced by increased gas transfer, but this requires quite a high degassing velocity, that it is not feasible practically. Regenerable oxygen absorbers have been used, but are considered impractical for scale-up. Irreversible oxygen absorbers can be used, like carbohydrates or other organic substrates, for respiration. When this substrate would have to be produced in the same process (for instance by the algae), it would reduce the overall solar efficiency by half because as many photons are needed for its production, as for $\mathrm{H}_{2}$ production.

Alternative processes, are the ones in which the photosynthetic water splitting and the $\mathrm{H}_{2}$ evolving reactions are separated in either time or place, the so-called indirect photobiolysis process.

In this case, the $\mathrm{O}_{2}$ inhibition is no longer a problem. One example of this system are the heterocystous cyanobacteria. Heterocysts are specialized cells in which the nitrogenase is protected from $\mathrm{O}_{2}$ inhibition, and are provided with substrates from the vegetative cells. Solar conversion efficiencies are generally low $(0.2-0.3 \%$ outdoors $)$ [1].

In another process [2], the green alga Chlamydomonas reinhardtii was alternated from a phase of photosynthetic $\mathrm{O}_{2}$ evolution and carbon accumulation to a phase of $\mathrm{H}_{2}$ production and consumption of metabolites. The latter phase is enforced by sulphur (S) deprivation. There is much discussion on whether this is truly a separation of the two reactions, or that the stress situation in which the culture is put by $\mathrm{S}$ deprivation causes all the $\mathrm{O}_{2}$ produced to be consumed for energy production.

So far no direct biophotolysis process has advanced beyond laboratory experimentation [1]. Apart from this, the process would produce a mixture of $\mathrm{H}_{2}$ and $\mathrm{O}_{2}$, which requires careful handling and separation. Melis has started a company working with the aforementioned process, but is not producing hydrogen on a commercial scale yet [3].

The nitrogenase enzyme that is used by the photoheterotrophic microorganisms and the heterocystous cells of cyanobacteria to produce $\mathrm{H}_{2}$, is also sensitive to oxygen $\left(\mathrm{O}_{2}\right)$. In this case, it is not a problem because no oxygen is produced during the process (anoxygenic photosynthesis). Another advantage is that the hydrogen production continues while the fermentation liquid is over saturated with hydrogen gas $\left(\mathrm{H}_{2}\right)$. Disadvantages of the process are that the nitrogenase enzyme requires extra energy in the form of ATP. This would reduce the photochemical efficiency if the ATP had to be derived from light energy.

The efficiency of transforming, for instance, a waste into accessible substrate and again into hydrogen, has to be taken into account. Furthermore, the substrates, the organic acids, are not always available, and perhaps some special energy crops will have to be cultivated.

$\mathrm{H}_{2}$ production from organic substrates would be bioenergetically more favourable than from water. However, photochemical efficiencies are low [1]. The reason for this would be that these bacteria saturate at even lower light intensities than microalgae. The photoheterotrophic organisms can use a wider part of the solar spectrum (higher wavelengths), but with associated lower energies.

\section{Photochemical efficiency}

Three important variables are used to evaluate the photobiological hydrogen production process: the efficiency with which light energy is used to produce energy in the form of hydrogen, the so-called photochemical efficiency (PE), the hydrogen production yield, and the yield coefficient of hydrogen produced relative to the carbon source consumed. Because we assume that the carbon source will be organic waste, and because the hydrogen yield is related to the PE, we concentrate here on the photochemical efficiency.

\subsection{Yields and photochemical efficiencies of photoautotrophic microorganisms}

There are some data on experimentally determined photochemical efficiencies for the photoautotrophic hydrogen production. Data found by Greenbaum [4] are presented in Table 1. The efficiencies are based on photosynthetic active radiation (PAR). This means that based on the total solar spectrum they would be 0.43 times the value. (see the 
Table 1

Energy conversion efficiencies of green algae for hydrogen and oxygen production [4]

\begin{tabular}{|c|c|c|c|c|}
\hline Alga & Absorbed light $\left(\mu \mathrm{W} \mathrm{cm}^{-2}\right)$ & Light on $\left(\right.$ no. $\left.{ }^{\mathrm{a}}\right)$ & $\mathrm{H} 2$ (nmolh) & Efficiency (PAR) $\left(\%^{b}\right)$ \\
\hline \multirow[t]{2}{*}{ Scenedesmus $\mathrm{D}_{3}$} & 5.1 & 1 & 126 & 16 \\
\hline & & 2 & 181 & 23 \\
\hline \multirow[t]{7}{*}{ C. reinhardtii (sup) } & 2.2 & 1 & 44 & 13 \\
\hline & & 2 & 54 & 16 \\
\hline & & 3 & 61 & 18 \\
\hline & & 4 & 64 & 19 \\
\hline & & 5 & 71 & 21 \\
\hline & & 6 & 71 & 21 \\
\hline & & 7 & 61 & 18 \\
\hline \multirow[t]{3}{*}{ C. reinhardtii (UTEX 90) } & 8.4 & 1 & 78 & 6 \\
\hline & & 2 & 104 & 8 \\
\hline & & 3 & 104 & 8 \\
\hline \multirow[t]{3}{*}{ C. moewusii } & 9.1 & 1 & 337 & 24 \\
\hline & & 2 & 309 & 22 \\
\hline & & 3 & 253 & 18 \\
\hline
\end{tabular}

${ }^{a}$ The entries in this column correspond to the ordinal number of successive periods of illumination. The light was on for either a 3- or 4-h period, after an equal period of darkness.

${ }^{\mathrm{b}}$ Conversion efficiency based on absorbed photosynthetically active radiation. PAR = photosynthetically active radiation. Based on repeated measurements and calibrations, it is estimated that the experimental error in these measurements is, at most, $\pm 15 \%$. The efficiencies were computed for the rates of hydrogen evolution at the end of the period of illumination when the algae were in a steady (or nearly steady) state.

section on theoretical photochemical efficiency). They would thus vary from $3 \%$ to $10 \%$. The efficiencies were calculated for a period of illumination after a dark period. However, it is important to observe that the oxygen produced in the reactor is immediately replaced by the helium gas, in a construction that does not seem very feasible for scale-up.

A conversion efficiency was estimated for the cyanobacterium Synechococcus sp. Miami BG043511 of 3.5\% based on PAR [5], which would be around $1.5 \%$ based on a total solar energy basis.

In contrast, the photochemical efficiency for $A$. cylindrica for outdoor hydrogen production was $0.2 \%$ [6].

Photochemical efficiencies for the photoautotrophic hydrogen production are only $3-10 \%$, when the oxygen is totally and immediately removed. In other processes it is about $1-2 \%$. As long as ways to overcome the oxygen inhibition have not been found, the photoautotrophic process is impractical for application in research dedicated to photobioreactor design and process optimization studies. When solutions to the oxygen inhibition might be found in the future, many outcomes of the research would be also applicable for the photoautotrophic process. Therefore, we continue to focus on the photoheterotrophic process only.

\subsection{Theoretical photochemical efficiency of photoheterotrophic bacteria}

With the help of data (if available) on quantum yields (number of moles of light photons needed to produce 1 mole of hydrogen), one can calculate the theoretical photochemical efficiency PE (efficiency with which light energy is needed to produce $\mathrm{H}_{2}$ energy). With the help of data on solar irradiance, the maximal hydrogen production per $\mathrm{m}^{2}$ at a certain geographical location can be estimated.

As discussed above, we choose to do this for photoheterotrophic bacteria. Similar calculations of photochemical efficiencies could be made for photoautotrophic organisms. However, in this case there is more uncertainty concerning the value of the basic data needed. Moreover, the theoretical photochemical efficiency if of limited meaning, because, in practice, oxygen inhibition occurs. Experimental data on photochemical efficiencies, however, if applicable, can be used to estimate maximal hydrogen production rates in a similar way as described below.

The photosynthetic efficiency (PE) is defined as energy stored as biomass produced per unit of light energy absorbed. The light energy absorbed can be based on the PAR range, the photosynthetically active radiation $(400-700 \mathrm{~nm}$ for green algae, and 400-950 nm for purple bacteria) or on the full solar irradiance (all wavelengths). Biomass yield (as protein or dry weight) on light energy can be used as a measure for efficiency. Because the intended product is energy (in the form of $\mathrm{H}_{2}$ ) and the limiting factor is light, the efficiency is best expressed on the basis of the energy produced per unit of light energy absorbed.

The efficiency by which the light energy (of, for instance, the sun) can be transformed into hydrogen gas energy, is dependent on the part of the energy that is absorbed by the antenna system of the plant, the energy loss during the several steps of excitation and electron transfers that follow. This efficiency can be calculated as described below. 


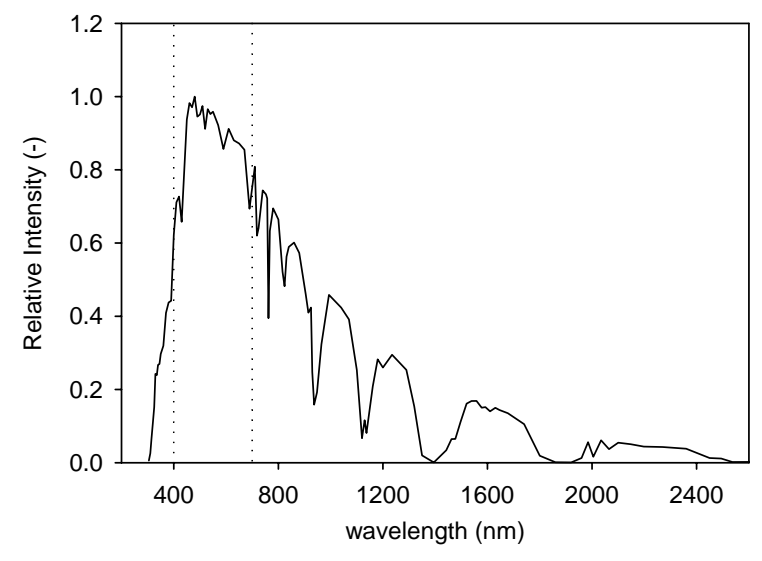

Fig. 3. Relative intensity on energy basis of sunlight at ground level [9].

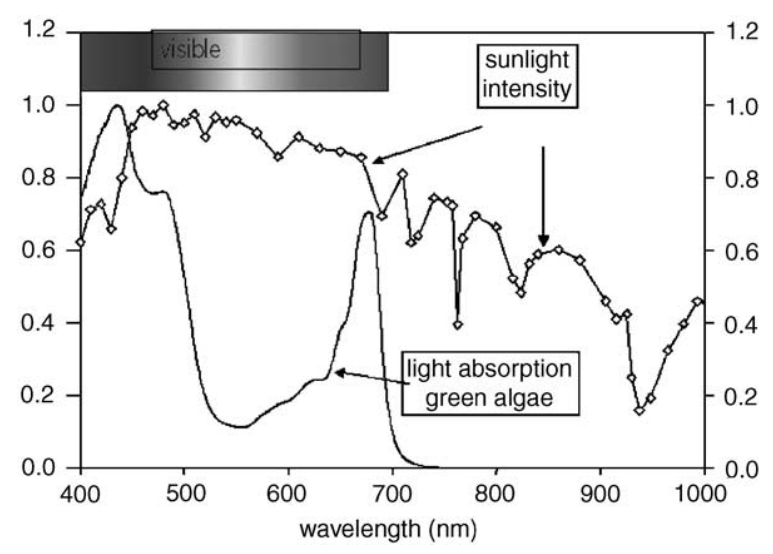

Fig. 4. Sunlight and light absorption by green algae.

Fig. 3 shows the light absorption spectrum of green algae (solid line) compared to the sunlight spectrum (dotted line). The $X$-axis represents the wavelength, with the visible part indicated by the coloured bar, and the relative light intensity shown on the $Y$-axis. Part of the sunlight energy from the spectrum is not absorbed by the green algae. For this reason, the efficiency of transformation of sunlight energy into hydrogen energy can never be $100 \%$.

Fig. 4 shows the light absorption spectrum of purple bacteria (solid line) compared to the sunlight (dotted line) spectrum. The $X$-axis represents the wavelength, with the visible part indicated by the coloured bar, and the relative light intensity shown on the $Y$-axis. Again the efficiency of light absorption is not $100 \%$.

It is important to note that these photoheterotrophic organisms also absorb light energy from the non-visible part of the spectrum.

In Fig. 5 the energy content of 1 mole of photons at two wavelengths (522 and $860 \mathrm{~nm}$, location of the absorption peaks of purple non-sulphur bacteria) is calculated. Göbel

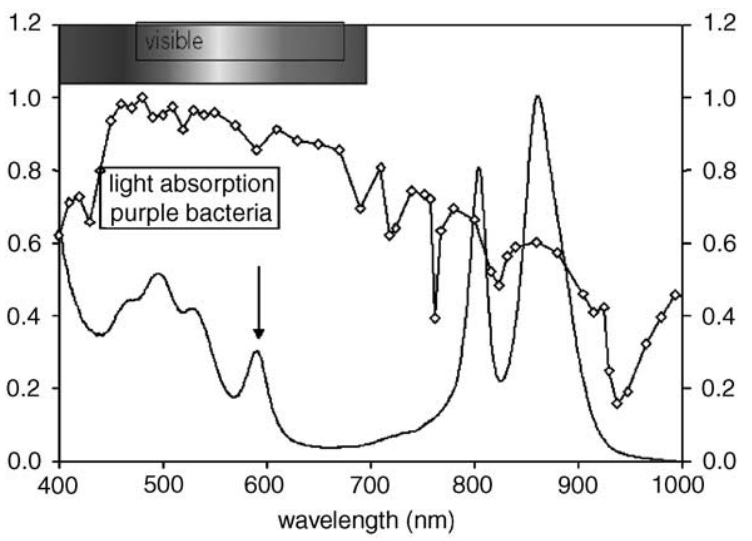

Fig. 5. Sunlight and light absorption by purple bacteria.

[7] determined the number of photons required to produce one ATP in photophosphorylation of Rhodopseudomonas species, as 1.5 photons per ATP, at $860 \mathrm{~nm}$. Miyake [8] estimated from this that the total reaction (four ATP) and electron elevations required 11 photons per $\mathrm{H}_{2}$ at $860 \mathrm{~nm}$. Analogous calculations (by ourselves) show that 14-15.8 photons are required per $\mathrm{H}_{2}$ at $522 \mathrm{~nm}$. The energy of 1 mole of photons depends on the wavelength, and is 0.229 and $0.139 \mathrm{MJ}$ at 522 and $860 \mathrm{~nm}$, respectively.

The photofermentation efficiency (PE) can be calculated as the ratio between energy gained in the form of hydrogen gas, and the energy needed in the form of photons. The energy of 1 mole of hydrogen is $0.29 \mathrm{MJ}$. Therefore, the $\mathrm{PE}$ is $8.4 \%$ and $19 \%$ at 522 and $860 \mathrm{~nm}$ wavelength, respectively (Fig. 5). The quantum yield at other wavelengths of the absorption spectrum are not known. However, data on quantum yields of other organisms have shown that the quantum yield is only little lower at wavelengths other than the absorption maximums. So the PE will accordingly be somewhat lower at other near-by wavelengths of the absorption spectrum. The overall PE over the whole of utilizable wavelengths of the absorption spectrum of the purple bacteria, is therefore, considering the relation with wavelength, estimated to be at least $10 \%$.

It should be noted that the energy content of the substrate and the energy fixed inside the biomass are neglected in the calculations. It is assumed that all energy required for the reaction and electron transport is derived from the light energy, and that the production of the substrate (requiring energy) is done elsewhere (for instance by making use of waste products).

\subsection{Maximal hydrogen production with sunlight as light source}

Sunlight is the ultimate energy source for microalgae. In Fig. 6 the relative light intensity of sunlight at ground level is shown. Although the wavelength range of solar radiation 

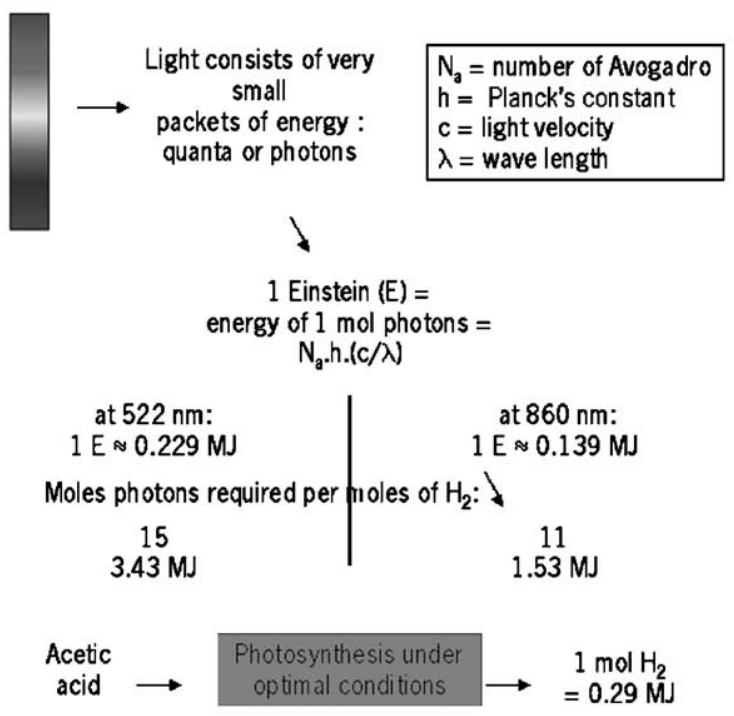

\section{PE: $0.29 / 3.43=8.4 \% \quad 0.29 / 1.53=19 \%$}

Overall of the utilizable wave lengths $\geq 10 \%$

Fig. 6. Photochemical efficiency of purple bacteria.

is very broad, only radiation between 400 and $700 \mathrm{~nm}$ can be used by microalgae (Fig. 3). This part of the solar spectrum is called 'Photosynthetic Active Radiation' (PAR) and is enclosed with dotted lines (Fig. 6). On an energy basis, 43\% of the solar radiation is in the PAR region [10].

For purple bacteria this PAR region is $400-950 \mathrm{~nm}$ (Fig. 4). On an energy basis $65.8 \%$ of the solar radiation is in this PAR region (own calculations based on Fig. 6 data).

The magnitude of solar radiation is dependent on the geographical position on Earth and the climatic conditions at that position. As an illustration the irradiance on a horizontal surface at two different geographical locations, Amsterdam and Sevilla is shown in Fig. 7. Global irradiance is the sum of the direct beam irradiance and the diffuse irradiance. The diffuse irradiance is caused by the scattering of light by small aerosols in the atmosphere and water droplets (clouds). In June, the monthly average global irradiance in Amsterdam is $18.0 \mathrm{MJ} \mathrm{m}^{-2} \mathrm{~d}^{-1}$, which is $68 \%$ of that in Sevilla, $26.6 \mathrm{MJ} \mathrm{m}^{-2} \mathrm{~d}^{-1}$. In Sevilla much more than half of the global radiation (69\% in June) reached ground level as direct beams. In Amsterdam this is less than half (49\% in June) because of more days with overcast skies.

In Fig. 8 the maximal $\mathrm{H}_{2}$ production is calculated on the basis of the different sunlight intensities at two different locations (Amsterdam and Sevilla). The maximal intensity in July of $25.78 \mathrm{MJ} \mathrm{m}^{-2} \mathrm{~d}^{-1}$ in Sevilla, corresponds with $257.8 \mathrm{GJ} \mathrm{ha}^{-1} \mathrm{~d}^{-1}$. Given the fact that only a part, $65.8 \%$ of this light is in the $400-950 \mathrm{~nm}$ region, and the
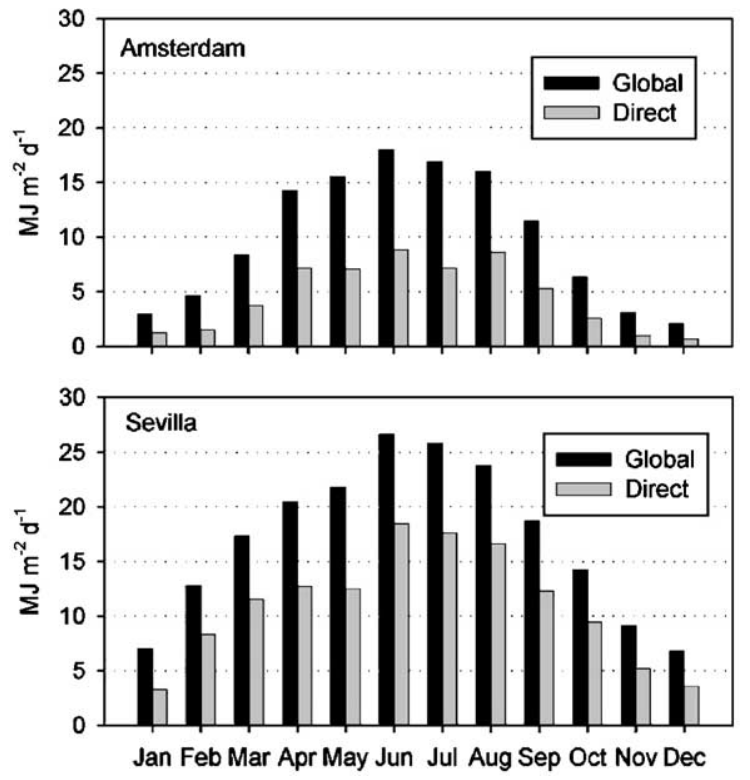

Fig. 7. Horizontal global and direct daily irradiance on ground level in: Amsterdam $52^{\circ} 21^{\prime} \mathrm{N}$ and Sevilla $37^{\circ} 22^{\prime} \mathrm{N}$ in 1996 and 1997 according to The European Database of Daylight and Solar Radiation [11].

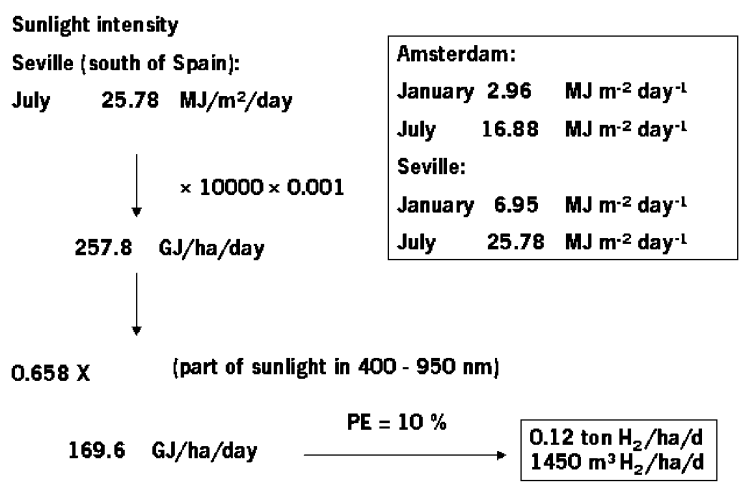

Fig. 8. Comparison of $\mathrm{H}_{2}$ production at locations with different solar irradiance (Amsterdam and Sevilla as examples).

theoretical photochemical efficiency is $10 \%$, the yield is $0.12 \mathrm{t} \mathrm{H}_{2} \mathrm{ha}^{-1} \mathrm{~d}^{-1}$. For Amsterdam, in July, this would be $0.078 \mathrm{tH}_{2} \mathrm{ha}^{-1} \mathrm{~d}^{-1}$.

\subsection{Yields and efficiencies of photoheterotrophic bacteria in practice}

The performance of photosynthetic bacteria with respect to biological hydrogen production must be evaluated on the basis of several parameters. One of them is the yield coefficient of $\mathrm{H}_{2}$ produced relatively to the carbon source consumed. Another important parameter is the efficiency of 
light, taking into account the $\mathrm{H}_{2}$ production rate and the $\mathrm{H}_{2}$ energy content, as well as the absorbed light. Although sun light is cheap (in outdoor experiments), the cost of large areas to capture sufficient light can be very high. Both yield coefficients and light efficiencies are not very abundant in the literature.

A search in recent literature enabled us to select the papers from which it was possible to get enough information to calculate the values of those parameters. The calculated values of yields and efficiencies were compared to the ones presented by the authors, when available, which also allowed us to validate our calculations, and these are shown in Table 2. The complete table, including data on reactor type, operations, and medium was published in [37], accompanied by a detailed evaluation of all calculations, assumptions and quality of available data.

The lab-scale experiments reported in Table 2 involved photofermentation with phototrophic bacteria in artificial culture media, with malate or lactate. References to complex media, such as residual wastewaters, were not included.

The hydrogen yield, as the number of moles of $\mathrm{H}_{2}$ produced per mole of carbon source consumed or as a percentage of the maximum value theoretically possible is not very often shown by the authors. Although we can only talk about yields when related to well-defined carbon sources, which are not the most important ones from a practical point of view, it seems that good yields can be achieved and this thus will not be a bottleneck in the $\mathrm{H}_{2}$ production.

The light efficiency is also not often referred to by the authors, first because there is more than one definition and second because it is not easy to present a value with certainty. All the values of light efficiency presented in Table 2 (which includes all the references we found with the necessary parameters available), both directly from literature and calculated by ourselves, were obtained using the same expression:

efficiency $(\%)=\mathrm{H}_{2}$ production rate $\times$

$\mathrm{H}_{2}$ energy content/absorbed light energy.

Although this definition of light efficiency is the most generally accepted one, each term of the equation can have associated errors:

(i) $\mathrm{H}_{2}$ production rate, as a productivity, is correct for continuous cultures but in batch cultures is a function of time. (ii) $\mathrm{H}_{2}$ energy content, as combustion enthalpy of $\mathrm{H}_{2}$, can be expressed as a net or gross calorific value (resp. $10.8 \mathrm{~J} \mathrm{ml}^{-1}$, and $12.7 \mathrm{~J} \mathrm{ml}^{-1}$ at $0^{\circ} \mathrm{C}$ and $1 \mathrm{~atm}$ ). (iii) The absorbed light energy has not been used, but the measured light intensity instead.

The energy content of the organic substrate and of the biomass is neglected in the calculations.

Our calculations of light efficiency could reproduce the values presented by the authors in most cases, and some differences could be attributed to differences in calculation [37]. Reasonable efficiencies were obtained at low light intensities $\left(7-9 \%\right.$ at $50 \mathrm{~W} \mathrm{~m}^{-2}$, and $26-35 \%$ at $13 \mathrm{~W} \mathrm{~m}^{-2}$ ) but the associated $\mathrm{H}_{2}$ production rates were too low to be interesting from a practical point of view.

The main bottleneck of biological hydrogen production seems not to be the $\mathrm{H}_{2}$ yield itself but light efficiency. This will determine the costs of photobioreactors and their operation.

The calculation of the theoretical photochemical efficiency was made for sunlight as light source. Only one of experiments referred in Table 2 was done with sunlight as light source, the rest is concerned with artificial light sources.

If the assumption can be made that the number of photons needed to produce 1 mole of hydrogen, does not depend very much on the wavelength (in the utilizable spectrum of wavelengths), and it is assumed that all available light is absorbed in the bioreactor, then the efficiencies found in Table 2 (with different kinds of artificial light) can be compared to the theoretical efficiency as calculated above (about $10 \%$ or more).

Efficiencies of about $10 \%$ or higher are reported in Table 2 , but as mentioned before, mostly at the lower light intensities, with generally associated lower $\mathrm{H}_{2}$ production rates.

\section{Photobioreactors}

A reactor for photobiological hydrogen production has to meet several conditions.

Since the hydrogen gas has to be collected, a prerequisite of the photobioreactor is for it to be an enclosed system. It has to be possible to maintain a monoculture for an extended time (it must be practical to sterilize the reactor). Preferably sunlight is the energy source.

The productivity of photobioreactor is light limited, and a high surface- to-volume ratio is a prerequisite for a photobioreactor. The photochemical efficiencies are low (theoretically a maximum of $10 \%$, and in laboratory experiments $10 \%$ and sometimes more, see above), and tend to decrease at higher light intensities (the effect of light saturation, photons cannot all be used for reaction energy but are dissipated as heat energy). This means that in order to create an efficient biological process, it is important to either dilute the light and distribute it as much as possible over the reactor volume, and/or mix the culture at a high rate, so that cells are light exposed only for a short period.

Janssen [38] reviewed three types of photobioreactors: the vertical column reactors (air-lift loop reactor and bubble column), flat panel reactor, and tubular reactors. He looked at the light gradients and the mixing-induced light/dark cycles, photosynthetic efficiency (PE), and scalability.

Depending on the reactor type and the way it is operated, cells are exposed for a certain period at the irradiated surface, or in a dark part of the reactor. The (mixing-induced) light/dark cycles, when they are in the range of micro or milli seconds, can enhance PE, approaching the PE's at low light intensities. When the cycles are from several seconds 
Table 2

Hydrogen production rate, yields and efficiencies of photoheterotrophic bacteria

\begin{tabular}{|c|c|c|c|c|c|}
\hline Strain & $I_{\text {energy }}$ & $\begin{array}{l}\mathrm{H}_{2} \\
\left(\mathrm{ml} \mathrm{ml} l_{\text {cult }}^{-1} h^{-1}\right)^{(1)}\end{array}$ & $\begin{array}{l}\text { Yield } \\
\left(\mathrm{H}_{2} / \mathrm{S}\right)(\%)\end{array}$ & $\begin{array}{l}\text { Efficiency } \\
\text { of light }(\%)\end{array}$ & Ref. \\
\hline $\begin{array}{l}\text { Rhodobacter } \\
\text { sphaeroides RV }\end{array}$ & $155 \mathrm{~W} \mathrm{~m}^{-2}$ & 0.131 & $56^{(\mathrm{b})}$ & $2.7^{(\mathrm{b})}$ & [12] \\
\hline $\begin{array}{l}\text { Rhodobacter } \\
\text { sphaeroides } \mathrm{RV}^{(2)}\end{array}$ & $\begin{array}{l}65 \mathrm{~W} \mathrm{~m}^{-2} \\
(850 \mathrm{~nm})\end{array}$ & $\begin{array}{l}0.054 \\
\left(0.6 \mathrm{mmol} \mathrm{m}^{-3} \mathrm{~s}^{-1}\right)\end{array}$ & & $3.7^{(b)}$ & [13] \\
\hline $\begin{array}{l}\text { Rhodobacter } \\
\text { sphaeroides } \mathrm{S}\end{array}$ & $\begin{array}{l}10 \mathrm{klx} \\
\left(35 \mathrm{~W} \mathrm{~m}^{-2}\right)\end{array}$ & $\begin{array}{l}0.019 \\
0.013^{(3)} \\
0.004^{(4)} \\
0.011^{(5)}\end{array}$ & $\begin{array}{l}38^{(b)} \\
28^{(b)} \\
8^{(b)}\end{array}$ & $\begin{array}{l}8.7^{(\mathrm{b})} \\
5.9^{(\mathrm{b})} \\
1.9^{(\mathrm{b})} \\
4.8^{(\mathrm{b})}\end{array}$ & [14] \\
\hline $\begin{array}{l}\text { Rhodobacter } \\
\text { sphaeroides O.U. } 001 \\
(D S M \text { 5648) }\end{array}$ & $\begin{array}{l}200 \mathrm{~W} \mathrm{~m}^{-2} \\
,\end{array}$ & $\begin{array}{l}0.020^{(6)} \\
0.002^{(7)} \\
0.004^{(8)}\end{array}$ & $\begin{array}{l}- \\
12^{(b)} \\
27^{(b)}\end{array}$ & $\begin{array}{l}1.1^{(b)} \\
0.1^{(b)} \\
0.2^{(b)}\end{array}$ & {$[15]$} \\
\hline $\begin{array}{l}\text { Rhodobacter } \\
\text { sphaeroides O.U. } 001\end{array}$ & $200 \mathrm{~W} \mathrm{~m}^{-2}$ & 0.006 & - & $0.2^{(b)}$ & [16] \\
\hline $\begin{array}{l}\text { Rhodobacter } \\
\text { sphaeroides RV }\end{array}$ & $\begin{array}{l}50001 \mathrm{x} \\
\left(45 \mathrm{~W} \mathrm{~m}^{-2}\right)\end{array}$ & 0.107 & $43^{(b)}$ & $11.3^{(b)}$ & [17] \\
\hline $\begin{array}{l}\text { Rhodopseudomonas sp. } \\
\text { Rhodospirillum } \\
\text { rubrum }\end{array}$ & $\begin{array}{l}10,0001 \mathrm{x} \\
300 \mathrm{~W} \mathrm{~m}^{-2}\end{array}$ & 0.065 & $\begin{array}{l}75^{(\mathrm{a})}-67^{(\mathrm{b})} \\
65^{(\mathrm{b})}\end{array}$ & $\begin{array}{l}\left(3.4^{(\mathrm{c})} / 1.9^{(\mathrm{d})}\right)^{(\mathrm{b}, *)} \\
2.8^{(\mathrm{b})}\end{array}$ & $\begin{array}{l}{[18]} \\
{[19]}\end{array}$ \\
\hline $\begin{array}{l}\text { MO006 } \\
\text { Rhodospirillaceae (?) }\end{array}$ & $10,000 \mathrm{~lx}$ & $\begin{array}{l}11.6 \mathrm{ml} \mathrm{h}^{-1} \\
\text { (highest rate ) }\end{array}$ & $\approx 80^{(\mathrm{b})}$ & $\left(5.1^{(\mathrm{c})} / 2.8^{(\mathrm{d})}\right)^{(\mathrm{b}, *)}$ & {$[20]$} \\
\hline $\begin{array}{l}\text { Rhodovulum sp. } \\
\text { NKPB160471R } \\
\text { (marine) and its }\end{array}$ & $\begin{array}{l}1800 \mathrm{~W} \mathrm{~m}^{-2} \\
13 \mathrm{~W} \mathrm{~m}^{-2}\end{array}$ & $\begin{array}{l}27 \mu \mathrm{mol} \mathrm{ml}^{-1} \mathrm{~h}^{-1} \\
2.4 \mu \mathrm{mol} \mathrm{ml}^{-1} \mathrm{~h}^{-1}\end{array}$ & & $\begin{array}{l}2^{(a)}-2.1^{(b)} \\
26^{(a)(b)}\end{array}$ & {$[21]$} \\
\hline $\begin{array}{l}\mathrm{H}-1 \text { uptake } \mathrm{H}_{2} \text {-ase } \\
\text { mutant }\end{array}$ & $\begin{array}{l}1800 \mathrm{~W} \mathrm{~m}^{-2} \\
13 \mathrm{~W} \mathrm{~m}^{-2}\end{array}$ & $\begin{array}{l}34 \mu \mathrm{mol} \mathrm{ml}^{-1} \mathrm{~h}^{-1} \\
3.2 \mu \mathrm{mol} \mathrm{ml}^{-1} \mathrm{~h}^{-1}\end{array}$ & & $\begin{array}{l}3^{(\mathrm{a})}-2.7^{(\mathrm{b})} \\
35^{(\mathrm{a})(\mathrm{b})}\end{array}$ & \\
\hline $\begin{array}{l}\text { Rhodobacter } \\
\text { sphaeroides RV }\end{array}$ & $\begin{array}{l}720 \mathrm{~W} \mathrm{~m}^{-2}(1 \mathrm{st}) \\
223 \mathrm{~W} \mathrm{~m}^{-2}(2 \mathrm{nd}) \\
72 \mathrm{~W} \mathrm{~m}^{-2}(3 \mathrm{rd}) \\
22 \mathrm{~W} \mathrm{~m}^{-2}(4 \mathrm{th})\end{array}$ & $\begin{array}{l}0.235(1 \mathrm{st})^{(9)} \\
0.210(2 \mathrm{nd}) \\
0.090(3 \mathrm{rd}) \\
0.025(4 \mathrm{th})\end{array}$ & $\begin{array}{l}13^{(\mathrm{b})} \\
11^{(\mathrm{b})} \\
5^{(\mathrm{b})} \\
1^{(\mathrm{b})}\end{array}$ & $\begin{array}{l}0.9^{(\mathrm{a})(\mathrm{b})}(1 \mathrm{st}) \\
2.5^{(\mathrm{a})}-2.6^{(\mathrm{b})}(2 \mathrm{nd}) \\
3.3^{(\mathrm{a})}-3.4^{(\mathrm{b})}(3 \mathrm{rd}) \\
3.2^{(\mathrm{a})}-3.1^{(\mathrm{b})}(4 \mathrm{th})\end{array}$ & {$[22,23]$} \\
\hline $\begin{array}{l}\text { Rhodopseudomonas } \\
\text { palustris } \mathrm{R}-1\end{array}$ & $434 \mathrm{~W} \mathrm{~m}^{-2}$ & & $-(10)$ & $\begin{array}{l}0.3^{(a)(b)(11)} \\
0.5^{(a)(12)}\end{array}$ & {$[24]$} \\
\hline $\begin{array}{l}\text { Rhodobacter } \\
\text { sphaeroides RV }\end{array}$ & $\begin{array}{l}\text { Max } 1 \mathrm{~kW} \mathrm{~m}^{-2} \\
\text { Integra1: (13),(14) } \\
6-7 \mathrm{kWh} \mathrm{m}^{-2} \\
\text { Max } 1 \mathrm{~kW} \mathrm{~m}^{-2} \\
\text { Integra1: (14),(15) } \\
7 \mathrm{kWh} \mathrm{m}^{-2}\end{array}$ & & $12^{(\mathrm{b})}$ & $2.2^{(\mathrm{a})}-(2-2.4)^{(\mathrm{b})}$ & {$[45]$} \\
\hline $\begin{array}{l}\text { Rhodobacter } \\
\text { sphaeroides RV }\end{array}$ & $330 \mathrm{~W} \mathrm{~m}^{-2}$ & $75 \mu \mathrm{mol} \mathrm{ml}^{-1}$ & $42^{(a)(b)}$ & $0.4^{(\mathrm{b}, *)}$ & {$[25]$} \\
\hline $\begin{array}{l}\text { Rhodobacter } \\
\text { capsulatus } \text { ST410 }\end{array}$ & $\begin{array}{l}66001 \mathrm{x} \\
\left(66 \mathrm{~W} \mathrm{~m}^{-2}\right)\end{array}$ & $\begin{array}{l}0.1^{(16)} \\
2.5 \mathrm{ml} \mathrm{ml}^{-1(17)}\end{array}$ & $\begin{array}{l}73^{(a)(b)} \\
84^{(a)}-83^{(b)}\end{array}$ & $4.8^{(\mathrm{b}, *)}$ & [26] \\
\hline
\end{tabular}


Table 2 (continued)

\begin{tabular}{|c|c|c|c|c|c|}
\hline Strain & $I_{\text {energy }}$ & $\begin{array}{l}\mathrm{H}_{2} \\
\left(\mathrm{ml} \mathrm{ml} l_{\text {cult }}^{-1} h^{-1}\right)^{(1)}\end{array}$ & $\begin{array}{l}\text { Yield } \\
\left(\mathrm{H}_{2} / \mathrm{S}\right)(\%)\end{array}$ & $\begin{array}{l}\text { Efficiency } \\
\text { of light }(\%)\end{array}$ & Ref. \\
\hline $\begin{array}{l}\text { Rhodobacter } \\
\text { sphaeroides RV }\end{array}$ & $30001 x$ & $\begin{array}{l}1.4-1.6^{(3)} \\
\left(11^{-1} \mathrm{~d}^{-1}\right)\end{array}$ & $(50-70)^{(\mathrm{a})}-7^{(\mathrm{b})}$ & $\left(2.5^{(\mathrm{c})} / 1.4^{(\mathrm{d})}\right)^{(\mathrm{b}, *)}$ & [27] \\
\hline $\begin{array}{l}\text { Rhodospirillum } \\
\text { rubrum }\end{array}$ & $100001 x$ & $0.048^{(3)}$ & $10^{(\mathrm{b})}$ & $\left(4.0^{(\mathrm{c})} / 2.2^{(\mathrm{d})}\right)^{(\mathrm{b}, *)}$ & [28] \\
\hline $\begin{array}{l}\text { Rhodospirillum } \\
\text { rubrum }\end{array}$ & $400 \mathrm{~W} \mathrm{~m}^{-2}$ & 0.18 & $80^{(\mathrm{b})}$ & $4.4^{(\mathrm{b})}$ & [29] \\
\hline $\begin{array}{l}\text { Rhodobacter } \\
\text { sphaeroides }\end{array}$ & $\begin{array}{l}50 \mathrm{~W} \mathrm{~m}^{-2} \\
1000 \mathrm{~W} \mathrm{~m}^{-2}\end{array}$ & $\begin{array}{l}1.45 \mathrm{~lm}^{-2} \mathrm{~h}^{-1} \\
7.91 \mathrm{~m}^{-2} \mathrm{~h}^{-1}\end{array}$ & & $\begin{array}{l}7.9^{(\mathrm{a})}-9.3^{(\mathrm{b})} \\
2.1^{(\mathrm{a})}-2.5^{(\mathrm{b})}\end{array}$ & {$[30]$} \\
\hline $\begin{array}{l}\text { Rhodobacter } \\
\text { sphaeroides O.U. } 001\end{array}$ & $4000 \mathrm{~lx}$ & 0.014 & $7^{(\mathrm{b})}$ & $\left(1.1^{(\mathrm{c})} / 0.6^{(\mathrm{d})}\right)^{(\mathrm{b}, *)}$ & {$[31]$} \\
\hline Rhodobacter marinus & $135 \mu \mathrm{Em}^{-2} \mathrm{~s}^{-1}$ & & & (18) & [32] \\
\hline $\begin{array}{l}\text { Rhodobacter } \\
\text { sphaeroides RV }\end{array}$ & $300 \mathrm{Wm}^{-2}$ & $\begin{array}{l}7812 \\
\left(\mathrm{ml} \mathrm{m}^{-2} \mathrm{~h}^{-1}\right)\end{array}$ & $(62-73)^{(a)}-47^{(b)}$ & $9.2^{(\mathrm{a})(19)}-8.3^{(\mathrm{b})}$ & {$[33,34]$} \\
\hline $\begin{array}{l}\text { Rhodobacter } \\
\text { capsulatus }\end{array}$ & $250 \mathrm{~W} \mathrm{~m}^{-2}$ & $0.080^{(3)}$ & $30^{(\mathrm{a})}-28^{(\mathrm{b})}$ & $1.3^{(b)}$ & {$[35]$} \\
\hline
\end{tabular}

Annotations: (a) given by authors; (b) calculated byourselves; (c)100 lx $=1 \mathrm{~W} \mathrm{~m}^{-2}$, according to Ooshima et al. [26]; (d)55.5 lx = $1 \mathrm{~W} \mathrm{~m}^{-2}$, according to Nakada et al. [36]; $(*)$ values calculated for efficiencies are not very accurate because (i) lux and different conversions to $\mathrm{W} \mathrm{m}^{-2}$ can be used, according to the kind of light source and sensor used, or (ii) the irradiation area was roughly estimated. Comments: (1) this is the default unit for hydrogen production rate, when other is not indicated; (2) mutant P3, UV irradiation; (3) nitrogen source was ammonium salt; (4) carbon source was acetate; (5) carbon source was a mixture of acetate and propionate; (6) semi-continuous, L-malic acid $7.5 \mathrm{mM}$, sodium glutamate $10 \mathrm{mM}$; (7) batch, L-malic acid $7.5 \mathrm{mM}$, sodium glutamate $10 \mathrm{mM}$; (8) batch, L-malic acid $30 \mathrm{mM}$, sodium glutamate $2 \mathrm{mM}$; (9) a batch photobioreactor with four flat compartments, see text; (10) carbon source was a mixture of acetate, propionate, butyrate and ethanol; (11) efficiency of light conversion to $\mathrm{H}_{2}$ for the long term (66 days); (12) efficiency of light conversion to $\mathrm{H}_{2}$ in the latter stage (8 days); (13) sun light; (14) light irradiation over a period of $12 \mathrm{~h}$ expressed in an integral way, by energy per unit of area; (15) halogen lamps; (16) with DL-malate $30 \mathrm{mM}$; (17) with acetate $30 \mathrm{mM}$; (18) the use of cells immobilized onto light-diffusing optical fibres did not enable the calculation of illuminated area and, consequently, the light efficiency; (19) highest value.

to tens of seconds, there is no improvement and even a decrease in PE has been reported.

The depth (and volume) of the photic zone depends on the dimensions and operations of the reactor, algal concentration, and the specific absorption coefficient of the algae (and the wavelength of the incoming light). On the basis of model calculations and or empirical data, several reactor types were compared. The results (for biomass production of photoautotrophs) are shown in Table 3.

Flat panel reactors show a high photochemical efficiency or biomass yield on light energy, while biomass density is also high.

Tubular reactors in theory should show better efficiencies because of the shorter average light/dark cycles. This is not supported by the data in Table 3, probably due to other factors.

The analysis of typical examples of microalgal cultivations in enclosed (outdoor) photobioreactors showed that the photosynthetic efficiency and productivity is determined by the light regime inside the reactors. In addition, only oxygen accumulation and shear stress limit productivity in certain designs.

The comparison of the bioreactors described above referred to processes with microalgae, diatoms or cyanobacteria. Though photoheterotrophic bacteria differ for instance in photochemical efficiency, absorption coefficient and size, the relative difference in performance of the reactor types might be extrapolated to the case of photoheterotrophics. The light regime, including mixing induced light/dark cycles are assumed to be much more determining than biological factors.

Considering the findings that flat panel reactors and tubular reactors (at least in theory) show highest efficiencies, it is worthwhile to look further into these two types of reactors, and their possibilities to be scaled up for practical purposes.

\subsection{Flat panel reactors}

Flat panel reactors consists of a rectangular transparent box with a depth of only $1-5 \mathrm{~cm}$. The height and width 
Table 3

Enclosed photobioreactors; photosynthetic efficiency (PE) and biomass yield on light energy $\left(Y_{\mathrm{dw}, \mathrm{E}}\right)$. After [38]

\begin{tabular}{|c|c|c|}
\hline Photobioreactor type & PE or $Y_{\mathrm{dw}, \mathrm{E}}^{\mathrm{a}, \mathrm{b}}\left(\%\right.$ or $\left.\mathrm{gdw} \mathrm{mol}^{-1}\right)$ & Reference (microorganism) \\
\hline $\begin{array}{l}\text { Bubble column and } \\
\text { air-lift column reactors: } \\
\text { - internal draught tube } \\
\text { — split cylinder }\end{array}$ & $0.84\left(Y_{\mathrm{dw}, \mathrm{E}}\right)^{\mathrm{c}}$ & $\begin{array}{l}{[39]} \\
\text { (Phaeodactylum tricornutum) }\end{array}$ \\
\hline Air-lift column & $0.82\left(Y_{\mathrm{dw}, \mathrm{E}}\right)$ & $\begin{array}{l}{[40]} \\
\text { (Phaeodactylum tricornutum) }\end{array}$ \\
\hline $\begin{array}{l}\text { Flat panel (a) vertical } \\
\text { (b) tilted }\end{array}$ & $\begin{array}{l}\text { (a) } 1.48\left(Y_{\mathrm{dw}, \mathrm{E}}\right) \approx 16(\mathrm{PE}) \\
\text { (b) } 10-20(\mathrm{PE})\end{array}$ & $\begin{array}{l}\text { (a) }[41] \\
\text { (b) }[42] \\
\text { (Spirulina platensis) }\end{array}$ \\
\hline Tubular reactor & $0.60\left(Y_{\mathrm{dw}, \mathrm{E}}\right) ; 6.5(\mathrm{PE})^{\mathrm{d}}$ & $\begin{array}{l}{[43]} \\
\text { (Spirulina platensis) }\end{array}$ \\
\hline $\begin{array}{l}\text { Tubular reactor } \\
\text { Diameter } 2.5 \mathrm{~cm} \\
\text { Diameter } 5.3 \mathrm{~cm}\end{array}$ & $\begin{array}{l}\text { (a) } 0.480-0.63\left(Y_{\mathrm{dw}, \mathrm{E}}\right)^{\mathrm{e}} \\
\text { (b) } 0.680-0.95\left(Y_{\mathrm{dw}, \mathrm{E}}\right)^{\mathrm{e}}\end{array}$ & $\begin{array}{l}{[44]} \\
\text { (Phaeodactylum tricornutum) }\end{array}$ \\
\hline
\end{tabular}

\footnotetext{
${ }^{a}$ Daily irradiance values in $\mathrm{MJ} \mathrm{m}^{-2} \mathrm{~d}^{-1}$ were divided by $12 \times 3600 \mathrm{~s}$, assuming a day length of $12 \mathrm{~h}$, multiplied with 0.429 , the fraction PAR in the solar spectrum [10], and multiplied with 4.57, mol photons $\mathrm{MJ}^{-1}$ [10].

${ }^{b}$ Monthly averages of daily solar irradiance on a vertical cylindrical surface in the same period of the year were obtained from the European Database of Daylight and Solar Radiation, www.satel-light.com [11].

${ }^{\mathrm{c}}$ Based on a linear growth phase with a productivity of about $0.49 \mathrm{~g}^{-1} \mathrm{~d}^{-1}$ observed in an outdoor batch culture in three different reactor types.

${ }^{\mathrm{d}}$ Before calculating PE and $Y_{\mathrm{dw}, \mathrm{E}}$, irradiance data were corrected for transmittivity tubes [43].

${ }^{\mathrm{e}}$ Calculated by Janssen [38].
}

can be varied to some extent, but in practice only panels with a height and width both smaller than $1 \mathrm{~m}$ have been studied. The photobioreactors are mixed with air introduced via a perforated tube at the bottom of the reactor. In order to create a high degree of turbulence, 2.84.21 of air per litre of reactor volume per minute has to be provided.

Usually the panels are illuminated from one side by direct sunlight and the panels are placed vertically, or inclined versus the sun. Light/dark cycles are short in these reactors, and this is probably the key factor leading to the high PE.

A disadvantage of these systems is that the power consumption of aeration (or mixing with another gas) is high, although mixing is always necessary in any reactor.

We believe it is very attractive to separate light collection from biological cultivation. Solar beam irradiation in 'clear-sky' areas can be collected and concentrated into optical fibres with lenses or parabolic mirrors. Via the fibres light can be guided into a large-scale photobioreactor. Presently, this is quite a costly solution, but when production costs of lenses, mirrors, solar tracking devices and optical fibres decreases because of increasing scale of demand, these cultivation techniques can be applicable generally.
In Fig. 9, the design of the large-scale flat-plate photobioreactors suggested by Janssen [38] is shown, next to the lab-scale flat-plate photobioreactor. Also, a prototype of the sunlight collector is shown that will be connected to the reactor and provide the light energy.

The large-scale flat-plate reactor is a rectangular air-lift photobioreactor with a large number of light re-distributing plates fixed a few centimetres from each other. Mixing will be provided by air (or gas) injected between adjacent plates and the culture liquid will rise in between. Only the space between the two most inner plates is not aerated and will act as a downcomer.

Many scaled-up versions of photobioreactors consist of repeating many of the smaller photobioreactor units, with its practical implications. Since the scaled-up reactor consists of only one unit, it is still practical to sterilize it and only one regulatory unit is needed.

\subsection{Tubular reactors}

Tubular photobioreactors consist of long transparent tubes with diametres ranging from 3 to $6 \mathrm{~cm}$, and lengths ranging from 10 to $100 \mathrm{~m}$. The culture liquid is pumped through these tubes by means of mechanical or air-lift pumps. The tubes can be positioned on many different 


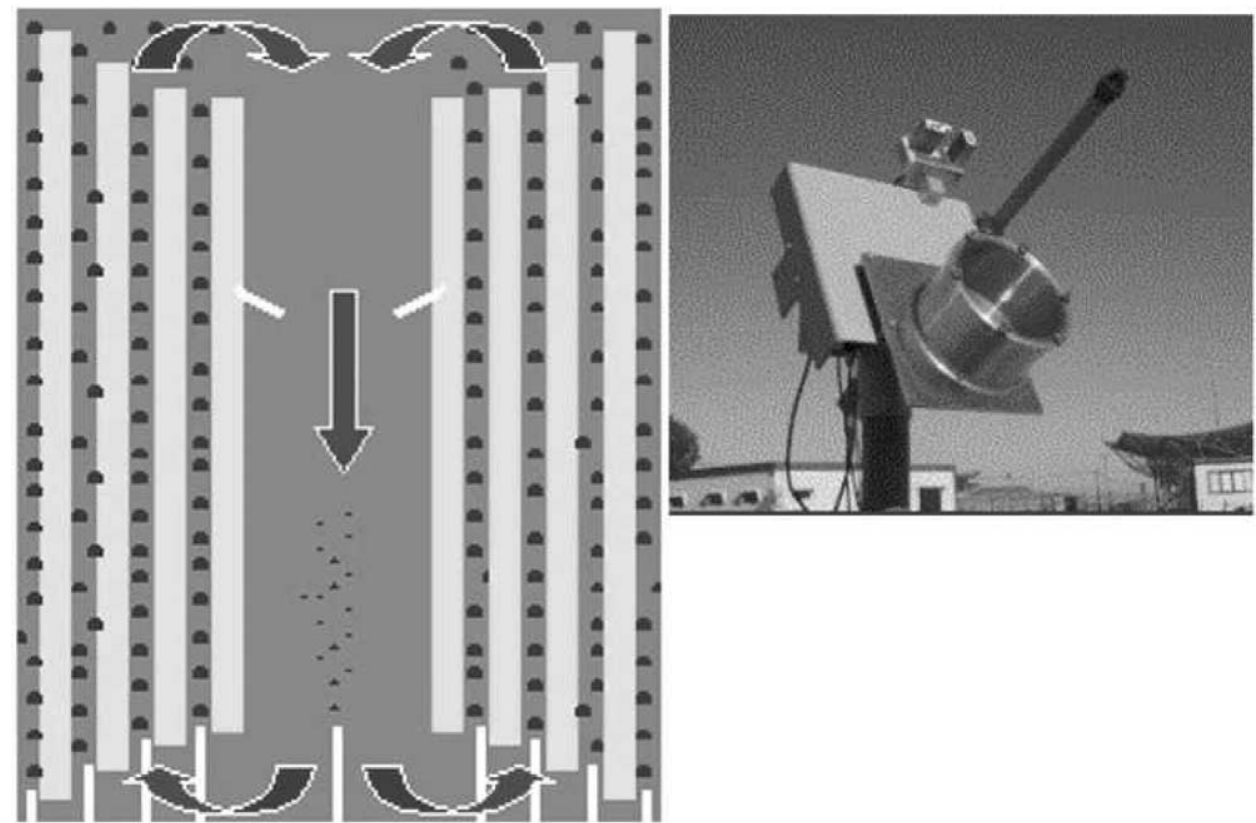

Fig. 9. The design of the large-scale flat-plate photobioreactor.

ways: in a horizontal plane as straight tubes with a small or large number of U-bends; vertical, coiled as a cylinder or a cone; in a vertical plane, positioned in a fence-like structure using U-bends or connected by manifolds; horizontal or inclined, parallel tubes connected by manifolds; in addition, horizontal tubes can be placed on different reflective surfaces with a certain distance between the tubes. Although tubular reactor design is very diverse, the predominant effect of the specific designs on the light regime is a difference in the photon flux density incident on the reactor surface $\left(\mathrm{PFD}_{\text {in }}\right)$. The shape of the light gradient in the tubes is similar in most designs. Also with respect to liquid mixing, i.e. light/day cycling, the circumstances in most designs are similar.

The length of the tubes is limited because of accumulation of gas (demonstrated for oxygen, and probably applicable for hydrogen), though this might not be so important for nitrogenase-based processes, since they may be less inhibited by $\mathrm{H}_{2}$. The way to scale-up is to connect a number of tubes via manifolds. This approach was chosen by the Institut fuer Getreideverarbeiting $\mathrm{GmbH}$ in Germany, in a reactor consisting of 25,000 glass tubes, divided in 20 units of $35 \mathrm{~m}^{3}$ and in total $12,000 \mathrm{~m}^{2}$ surface. It is used for production of the alga Chlorella sp.

\section{Discussion}

The few data found on PE of the photoautotrophic hydrogen production support the theory that oxygen inhibition leads to low PEs.
The theoretical photochemical efficiency of the photo heterotrophic process is low, $10 \%$, the efficiencies found in literature generally are even lower.

When the PE would be maximal at all light intensities, still a large surface would be needed to reach a reasonable hydrogen production. In the Netherlands (average of 2.96 and $16.88 \mathrm{~m}^{2}$ day $^{-1}$ ), $420 \mathrm{~h}$ would be needed for the production of 1 GJ of hydrogen per year. In southern Spain, this would be $250 \mathrm{~h}$.

The productivity of photobioreactors is determined by the light regime inside the reactors. Optimizing the reactors in this respect, and optimizing the reactor surface are crucial for making the photobiological hydrogen production successful.

\section{Acknowledgements}

This project was realised thanks to a contribution from Novem, project nr 249.402-0180.

\section{References}

[1] Benemann JR. Biohydrogen: approaches and potential. In: Proceedings of the 11th Canadian Hydrogen Conference, Victoria, BC June 17-20, 2001.

[2] Melis A, Zhang L, Forestier M, Chirardi ML, Seibert M. Sustained photobiological hydrogen gas production upon reversible inactivation of oxygen evolution in the green alga Chlamydomonas reinhardtii. Plant Physiol 2000;122:127-35.

[3] Internet: http://www.melisenergy.com, 2002. 
[4] Greenbaum E. Energetic efficiency of hydrogen photoevolution by algal water splitting. Biophys J 1988;54:365-8.

[5] Kumazawa S, Mitsui A. Efficient hydrogen photoproduction by synchronously grown cells of a marine cyanobacterium, Synechococcus $\mathrm{sp}$. Miami BG 043511, under high cell density conditions. Biotech Bioeng 1994;44:854-8.

[6] Myamoto K, Benemann JR, Hallenbeck PC. Solar energy conversion by nitrogen limited cultures of Anabaena cylindrical. J Ferment Technol 1979;57:287-93.

[7] Göbel F. Quantum efficiencies of growth. In: Clayton RK, Sistrom WR, editors. Photosynthetic bacteria. New York: Plenum Press, 1978. p. 907-25.

[8] Miyake J. The science of biohydrogen. In: Zaborsky OR, editor. Biohydrogen. London: Plenum Press, 1998. p. 7-18.

[9] American Society for Testing and Materials, ASTM, spectrum E892.

[10] Thimijan RW, Heins RD. Photometric, radiometric and quantum light units of measure: a review of procedures for interconversion Hort Sci 1983;18(6):818-22.

[11] Fontoynont M, Dumortier D, Heinemann D, Hammer A, Olseth J, Skarveit A, Ineichen P, Reise Ch, Page J, Roche L, Beyer HG, Wald L. Satellight: a www server which provides high quality daylight and solar radiation data for western and central Europe. Proceedings of the Ninth Conference on Satellite Meteorology and Oceanography, Paris, 1998.

[12] El-Shishtawy RMA, Kitajima Y, Otsuka S, Kawasaki S, Morimoto M. Study on the behavior of production and uptake of photobiohydrogen by photosynthetic bacterium Rhodobacter sphaeroides RV. In: Zaborsky OR, editor. Biohydrogen. London: Plenum Press, 1998. p. 117-38.

[13] Miyake M, Sekine M, Vasilieva LG, Nakada E, Wakayama T, Asada Y, Miyake J. Improvement of bacterial light-dependent hydrogen production by altering the photosynthetic pigment ratio. In: Zaborsky OR, editor. Biohydrogen. London: Plenum Press, 1998. p. 81-6.

[14] Sasaki K. Hydrogen and 5-aminolevulinic acid production by photosynthetic bacteria. In: Zaborsky OR, editor. Biohydrogen. London: Plenum Press, 1998. p. 133-75.

[15] Eroglu I, Aslan K, Gündüz U, Yücel M, Türker L. Continuous hydrogen production by Rhodobacter sphaeroides O.U. 001. In: Zaborsky OR, editor. Biohydrogen. London: Plenum Press, 1998. p. 143-51.

[16] Türkarslan S, Yigit DO, Aslan K, Eroglu I, Gündüz U. Photobiological hydrogen production by Rhodobacter sphaeroides O.U. 001 by utilization of waste water from milk industry. In: Zaborsky OR, editor. Biohydrogen. London: Plenum Press, 1998. p. 151-6.

[17] Khatipov E, Miyake M, Miyake J, Asada Y. Polyhydroxybutyrate accumulation and hydrogen evolution by Rhodobacter sphaeroides as a function of nitrogen availability. In: Zaborsky OR, editor. Biohydrogen. London: Plenum Press, 1998. p. 157-217.

[18] Kim JS, Ito K, Takahashi H. Production of molecular hydrogen by Rhodopseudomonas sp. J Ferment Technol 1981;59(3):185-274.

[19] Zürrer H, Bachofen R. Hydrogen production by the photosynthetic bacterium Rhodospirillum rubrum. Appl Environ Microbiol 1979;37(5):789-881.

[20] Matsumoto M, Yoza B, Radway JC, Zaborsky OR. Photosynthetic bacteria of Hawaii: potential for hydrogen production. In: Zaborsky OR, editor. Biohydrogen. London: Plenum Press, 1998. p. 163-8.
[21] Yamada A, Hatano T, Matsunaga T. Conversion efficiencies of light energy to hydrogen by a novel Rhodovulum sp. and its uptake-hydrogenase mutant. In: Zaborsky OR, editor. Biohydrogen. London: Plenum Press, 1998. p. 167-237.

[22] Nakada E, Asada Y, Arai T, Miyake J. Light penetration into cell suspensions of photosynthetic bacteria and relation to hydrogen production. J Ferment Bioeng 1995;80(1):53-9.

[23] Nakada E, Nishikata S, Asada Y, Miyake J. Light penetration and wavelength effect on photosynthetic bacteria culture for hydrogen production. In: Zaborsky OR, editor. Biohydrogen. London: Plenum Press, 1998. p. 345-98.

[24] Otsuki T, Uchiyama S, Fujiki K, Fukunaga S. Hydrogen production by a floating-type photobioreactor. In: Zaborsky OR, editor. Biohydrogen. London: Plenum Press, 1998. p. 369-442.

[25] Hillmer P, Gest H. $\mathrm{H}_{2}$ metabolism in the photosynthetic bacterium Rhodopseudomonas capsulata: $\mathrm{H}_{2}$ production by growing cultures J Bacteriol 1977;129(2):724-54.

[26] Ooshima H, Takakuwa S, Katsuda T, Okuda M, Shirasawa T, Azuma M, Kato J. Production of hydrogen by a hydrogenase-deficient mutant of Rhodobacter capsulatus. J Ferment Bioeng 1998;85(5):470-4.

[27] Fascetti E, Todini O. Rhodobacter sphaeroides RV cultivation and hydrogen production in a one- and two-stage chemostat. Appl Microbiol Biotechnol 1995;44:300-4.

[28] Miyake J, Tomizuka N, Kamibayashi A. Prolonged photo-hydrogen production by Rhodospirillum rubrum. J Ferment Technol 1982;60(3):199-203.

[29] Zürrer H, Bachofen R. Aspects of growth and hydrogen production of the photosynthetic bacterium Rhodospirillum rubrum in continuous culture. Biomass 1982;2:165-238.

[30] Miyake J, Kawamura S. Efficiency of light energy conversion to hydrogen by the photosynthetic bacterium Rhodobacter sphaeroides. Int J Hydrogen Energy 1987;12(3):147-55.

[31] Sasikala C, Ramana CV, Rao R. Environmental regulation for optimal biomass yield and photoproduction of hydrogen by Rhodobacter sphaeroides O.U. 001. Int J Hydrogen Energy 1991;16(9):597-601.

[32] Yamada A, Takano H, Burgess JG, Matsunaga T. Enhanced hydrogen production by a marine photosynthetic bacterium, Rhodobacter marinus, immobilized onto light-diffusing optical fibers. J Mar Biotechnol 1996;4:23-9.

[33] El-Shishtawy RMA, Kawasaki S, Morimoto M. Biological $\mathrm{H}_{2}$ production using a novel light-induced and diffused photoreactor. Biotechnol Techn. 1997;11(6):403-9.

[34] El-Shishtawy RMA, Kawasaki S, Morimoto M. Cylindrical-type induced and diffused photobioreactors: a novel photoreactor for large-scale $\mathrm{H}_{2}$ production. In: Zaborsky OR, editor. Biohydrogen. London: Plenum Press, 1998. p. 353-60.

[35] Tsygankov AA, Fedorov AS, Laurinavichene TV, Gogotov IN, Rao KK, Hall DO. Actual and potential rates of hydrogen photoproduction by continuous culture of the purple non-sulphur bacterium Rhodobacter capsulatus. Appl Microbiol Biotechnol 1998;49:102-8.

[36] Nakada E, Nishikata S, Asada Y, Miyake J. Hydrogen production by gel-immobilized cells of Rhodobacter sphaeroides - distribution of cells, pigments, and hydrogen evolution. J Mar Biotechnol 1996;4:38-42.

[37] Rocha JS, Barbosa MJ, Wijffels RH. Hydrogen production by photosynthetic bacteria: culture media, yields and efficiencies. 
In: Myake J, Matsunaga T, San Pietro A, editors. Biohydrogen II. Oxford: Elsevier Science, 2001. p. 3-32.

[38] Janssen M. Cultivation of microalgae: effect of light/dark cycles on biomass yield. Thesis, Wageningen University, Wageningen, the Netherlands, 2002.

[39] Miron AS, Camacho FG, Gomez AC, Grima EM, Chisti MY. Bubble-column and airlift photobioreactors for algal culture. A.I.Ch.E. J 2000;46:1872-87.

[40] Camacho FG, Comez AC, Fernandez FGA, Sevilla JMF, Grima EM. Use of concentric-tube airlift photobioreactors for microalgal outdoor mass cultures. Enzyme Microb Tech 1999;24:161-72.

[41] Hu Q, Richmond A. Productivity and photosynthetic efficiency of Spirulina platensis as affected by light intensity, algal density and rate of mixing in a flat plate photobioreactor. $\mathrm{J}$ Appli Phycol 1996;8:139-45.

[42] Hu Q, Faiman D, Richmond A. Optimal tilt angles of enclosed reactors for growing photoautotrophic microorganisms outdoors. J Ferment Bioeng 1998;85:230-6.
[43] Torzillo G, Accolla P, Pinzani E, Masojidek J. In situ monitoring of chlorophyll fluorescence to assess the synergistic effect of low temperature and high irradiance stresses in Spirulina cultures grown outdoors in photobioreactors. J Appl Phycol 1996;8:283-91.

[44] Fernandez FGA, Camacho FG, Perez JAS, Sevilla JMF, Grima EM. Modelling of biomass productivity in tubular photobioreactors for microalgal cultures: effects of dilution rate, tube diameter, and solar irradiance Biotech Bioeng 1998;58:605-16.

[45] Wakayama T, Toriyama A, Kawasugi T, Arai T, Asada Y, Miyake J. Photohydrogen production using photosynthetic bacterium Rhodobacter sphaeroides RV: simulation of the light cycle of natural sunlight using an artificial source. In: Zaborsky OR, editor. Biohydrogen. London: Plenum Press, 1998. p. $375-455$. 